EMBRYARIDDLE
Aeronautical University

SCHOLARLY COMMONS
International Journal of Aviation, Aeronautics, and Aerospace

\title{
The Military Learner: The Acceptance of New Training Technology for C-130 Aircrews
}

\author{
Michael Hathaway \\ Lockheed-Martin, mchathaway39@gmail.com \\ David Cross \\ Embry-Riddle Aeronautical University, crossaf6@erau.edu
}

Follow this and additional works at: https://commons.erau.edu/ijaaa

Part of the Educational Methods Commons

\section{Scholarly Commons Citation}

Hathaway, M., \& Cross, D. (2016). The Military Learner: The Acceptance of New Training Technology for C-130 Aircrews. International Journal of Aviation, Aeronautics, and Aerospace, 3(2). https://doi.org/ 10.15394/IJAAA.2016.1102

This Article is brought to you for free and open access by the Journals at Scholarly Commons. It has been accepted for inclusion in International Journal of Aviation, Aeronautics, and Aerospace by an authorized administrator of Scholarly Commons. For more information, please contact commons@erau.edu. 
As the Department of Defense (DOD) funding and manpower resources have been reduced, the focus on cost-effective training methods has become critical (Farrell, 2014). These budget reductions affected the United States Air Force (USAF) and Little Rock Air Force Base (LRAFB) C-130 Aircrew Training System (ATS) flight school (Hofheimer, 2010). Although the budget was reduced, the required student output remained the same, which caused managers to revise the training syllabus. A portion of actual flights were replaced by simulator flights and the cost per training hour was reduced to one tenth of the original flight hour (Koblen \& Kovacova, 2012). Academic trainers were also replaced with less expensive computer based training (CBT) technology which was adapted specifically for C-130 aircraft.

The 360-degree lessons were computer based lessons that were added to the curriculum that showed a 360-degree view of the specific training area selected by the lesson designer (i.e., C-130 flight deck, cargo compartment, and aircraft exterior) (Steenberge \& Wiegand, 2011). This technical adaptation, unique to the C-130 Aircrew Training System, was designed for the government by courseware developers (Steenberge \& Wiegand, 2011). The capability allowed students to take a virtual tour, review checklist responses, and practice aircraft procedures.

A challenge with new technology was that learners demanded professional visual graphics when learning complex information (Koblen \& Kovacova, 2012; Schofield, 2012; United States Air Force [USAF], 2012). In the ATS, the provided training programs were mandatory. A danger associated with mandatory use environments was that learners who did not wholeheartedly accept the innovation may have under-utilized the system; under-use could diminish aircrew member flight safety (Ghazizadeh, Lee, \& Boyle, 2012). The acceptance for this 360-degree training program technology by military learners was unknown.

How well did aircrew members accept the new technology for training? The Technology Acceptance Model (TAM) has been used in multiple cases to resolve similar questions (Ghazizadeh et al., 2012). Constructs from the TAM included: perceived usefulness (PU), perceived ease of use (PEOU), subjective norm (SN), and voluntariness (V) (Lee \& Chang, 2011; Venkatesh\& Davis, 2000). The TAM3 model was specifically chosen because it provided USAF managers, who contracted and paid for new training, an insight to why military learners accept new technology. 


\section{Literature Review}

\section{The Technology Acceptance Model}

The technology acceptance model (TAM) has been used in multiple cases to study the acceptance of new technology. The TAM has been grounded in the theories of reasoned action (TRA) and planned behavior (TPB) to study attitudes toward new information technologies (Ajzen, 1991; Fishbein \& Ajzen, 1975). According to the TRA, human behavior was affected by behavioral intention, attitude, and subjective norm (Fishbein \& Ajzen, 1975). The TPB was developed as an extension of the TRA to explain actions caused by a situation beyond one's control (Holden\& Karsh, 2010). As an extension of these theories, the TAM has been used to explain acceptance of new computer technologies and applications (Mardis, Hoffman, \& Marshall, 2008). Researchers have studied the perceived usefulness (PU) and perceived ease of use (PEOU) constructs to extend the understanding of technology acceptance and to learn more about extrinsic and intrinsic motivation factors (Dass, Dabbagh,\& Clark, 2011).

Two constructs, perceived usefulness (PU) and perceived ease of use (PEOU) have been used abundantly in studies that concern usage intention (Venkatesh \& Davis, 2000). Multiple studies of TAM have yielded many competing models, each with different sets of acceptance determinants (Fillion, Braham, \& Ekionea, 2012). Improvements in the TAM have been used to extend the dialogue about technology acceptance and the theories from which TAM was derived.

Technology Acceptance Model 2 (TAM2). The TAM2 was an extension of TAM that focused on perceived usefulness (PU) and included two additional constructs: the subjective norms (SN) and voluntariness (V) (Holden \& Karsh, 2010). When individuals behaved in a certain manner because they felt it would please people who were important in their life, they acted to appease a subjective norm (Venkatesh \& Davis, 2000). When individuals acted in a manner that they felt was non-mandatory, they acted under the voluntariness construct (Venkatesh \& Davis, 2000).

Technology Acceptance Model 3 (TAM3). Continued evolution of TAM research resulted in the TAM3 which provided a list of determinants specific for the PEOU construct (Venkatesh \& Bala, 2008). The PEOU determinants included: computer self-efficacy, perception of external control, computer anxiety, computer playfulness, perceived enjoyment, and objective usability (Venkatesh \& Bala, 2008). 
This research included a series of interview questions developed around the TAM constructs and field tested before they were used. The population came from military learners who have used the new 360-degree technology to complete their training. The sample participants came from Arkansas' Little Rock Air Force Base. Each participant provided personal experiences which contributed to the study.

\section{Statement of the Problem}

The problem explored in this study was military learner acceptance of a new technology designed and mandated for use in training in a time of deep funding cuts in the Department of Defense (DOD). Despite cuts, DOD and industry leaders were charged with completing critical military training in the midst of shrinking budgets (Dunlap, 2011; Gates, 2010; Hofheimer, 2010). To remain within budget constraints, USAF leaders endorsed new technology as a replacement for traditional training methods (Steenberge \& Weigand, 2011; USAF, 2012). One requirement set by USAF trainers for newly implemented training technology was that it had to be accepted by learners (USAF, 2012). Technology acceptance has been cited as a problem for years in: information technology (IT) programs (Chutter, 2009; Hu \& Tsai, 2009; Mangin, Bourgault, Leon, \& Guerrero, 2012; Quazi \& Talukder, 2011), education cases (Schofield, 2012), on-line learning (Cane, McCarthy, \&Halawi, 2010) and in mandatory use environments (Gafni, Shaul, \& Tauber, 2011; Ghazizadeh et al., 2012; Yousafzai, Foxall, \& Pallister, 2007). Throughout the literature, the Technology Acceptance Model (TAM) has been used effectively to improve an understanding of the Theories of Reasoned Action and Planned Behavior (Venkatesh, 2010). The specific problem explored in this study was military learner acceptance of a new technology designed and mandated for use in training (Cane et al., 2010). It was unclear exactly how the TAM could be used to explain technology acceptance while training military learners (Alias, 2012; Gafni et al., 2011). However, the TAM3 was applied in this mandatory learning context to identify acceptance gaps and to communicate these to industry and military training managers. If these acceptance gaps continued, then resulting training may be affected (Ghazizadeh et al., 2012; Talukder, 2012). In critical fields such as aviation, eliminating training gaps has been vital in the survival of aircrew, passengers, and equipment (Jennings, 2010; USAF, 2012).

\section{Purpose of the Study}

The purpose of this qualitative embedded single-case study was to explore military learner acceptance of a new technology designed and mandated for use in training. The embedded units of the study included military learner participants who underwent C-130 aircrew training (Yin, 2012). Interview questions were 
designed around constructs of the TAM3: PEOU, PU, SN, and V. Previous research studies in laboratory situations have provided the theoretical basis for explaining acceptance of technology. However, for these research questions and problem, a study conducted in the field was appropriate (Yousafzai, Foxall, \& Pallister, 2007b). This population of interest was composed of military learners who were experienced with a specific training technology. A sample of 18 participants were selected from Arkansas' Little Rock Air Force Base. This sample size was sufficient to communicate personal experiences in the personal interview process, given the study's narrow objectives and homogeneity of military learners (Cane, McCarthy, \& Halawi, 2010; Patton, 2002). An analysis of evidence using pattern matching compared to reviewed literature was used to help build a deeper understanding of technology acceptance in mandatory situations (Yin, 2009; Baxter \& Jack, 2008).

Technology Acceptance Model (TAM). The Technology Acceptance Models were based upon the theories of reasoned action and planned behavior. The basic assumption of the TRA was that a person performed a specific behavior because of their perception of positive or negative favorableness toward the behavior (Fishbein \& Ajzen, 1975). Behavioral intention was the essential factor in human behavior as suggested in the TPB. Researchers also found that behavioral intention was comprised of three determinants: attitude, subjective norm, and perceived behavioral control (Ajzen, 1991; Holden\& Karsh, 2010). The TAM includes the TRA's indirect influence of attitudes however it uses two more specific constructs: perceived usefulness and perceived ease-of-use (Davis, 1989; Hedman \& Gimpel, 2010).

As an extension of TAM, TAM2 added several variables to the PU construct and incorporated fresh constructs of subjective norms (SN), experience, and voluntariness (V; Palomäki, Stigzelius, \&Vartiainen, 2010). When an individual behaves in a certain manner that they feel it would please people who are important to them, they are acting because of SN (Venkatesh\& Davis, 2000). Voluntariness is demonstrated by an individual who acts in a manner that was not mandatory (Venkatesh \& Davis, 2000). The TAM3 also added to the self-efficacy and hedonistic dimension of the PEOU construct. This extension included computer self-efficacy, perceptions of external control, computer anxiety, and computer playfulness as well as perceived enjoyment and objective usability (Daniel, 2011; Venkatesh \& Bala, 2008). Figure 1 illustrates the relationships of the different variables comprising the TAM3.

TAM constructs. The constructs of $P U$ and PEOU have been used to study TAM (Venkatesh, 1999). During this research, these constructs were explored to determine the level of learner acceptance of the new technology. Traditionally, 
researchers have found that PU is an important aspect of Internet purchasing (Piraman, 2011). The easier technology is to use the greater the attraction and intention to use it (Hu \& Tsai, 2009). It is important as a syllabus and lesson developer to make the lesson material and the equipment useful for the learner as a means to meet the learning objective. Intrinsic motivation in education is affected by PEOU and perceived enjoyment (Hu \&Tsai, 2009), while extrinsic motivation has been linked to influences from peers, instructors, and commanders.

The following model illustrated the TAM which consisted of the Perceived Usefulness, Perceived Ease of Use, Behavioral Intention, and Use Behavior constructs. The TAM2 portion of the illustration added: Subjective Norm, Experience, Voluntariness, Image, Job Relevance, Output Quality, and Results Demonstrability. The TAM3 added the Anchor construct which included: Computer Self-efficacy, Perception of External Control, Computer Anxiety, and Computer Playfulness. Finally included were the TAM3 Adjustment constructs: Perceived Enjoyment and Objective Usability.

\section{Research Questions}

Research questions developed for this study were designed to enhance the understanding of the individual and contextual factors that influence military learners' acceptance of the new 360-degree technology for C-130 aircrew training (Venkatesh, 2010). The interview protocol included several sub-questions; their purpose was to help the researcher understand the participant's acceptance of technology (see Appendix).

Q1. What reasons do military aircrews give for accepting new training technologies?

Q2. Why do military learners accept the new technology provided in the training program?

Q3. How do military learners perceive the value of the training in relation to the TAM3 factors? 


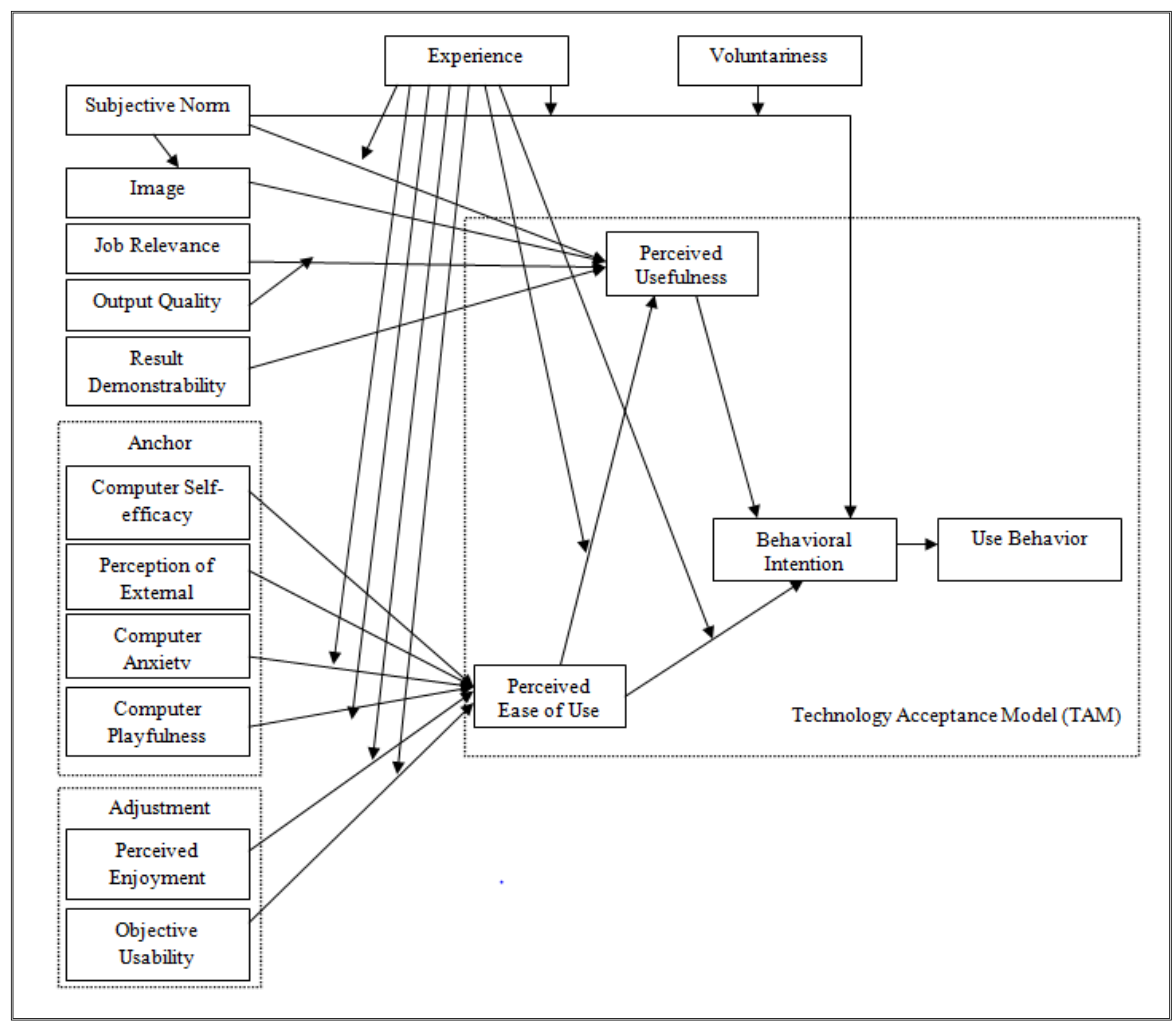

Figure 1. Technology Acceptance Model 3 (TAM3). Adapted from “Technology Acceptance Model 3 and A Research Agenda on Interventions," by V. Venkatesh, and H. Bala, 2008, Decision Sciences, 39 (2), 272-315. Reprinted with permission.

\section{Method}

During this qualitative embedded single-case study the researcher explored military learner acceptance of new technology that was designed and mandated for use in training. A better understanding of technology acceptance was gained through the examination of four specific constructs: perceived usefulness (PU), perceived ease of use (PEOU), subjective norm (SN), and voluntariness (V) from the perspective of military learners who used the new technology incorporated in the 360-degree lessons.

\section{Design}

The TAM3 model was chosen because it provided a thorough description of the Perceived Ease of Use construct (Venkatesh, 2010). When technology has been mandated for use in training situations, sometimes learners were distracted by various factors that detract from training and adversely affect learning (Gafni et al., 
2011; Ghazizadeh et al., 2012). By using the TAM3 constructs of: computer selfefficacy, perceptions of external control, computer anxiety, computer playfulness, perceived enjoyment and objective usability (Daniel, 2011; Venkatesh \& Bala, 2008) this research explored the reasons learners gave for acceptance of new technology in mandatory situations.

\section{Sample}

Participants were military learners that attended C-130 aircrew training at Little Rock Air Force Base, Arkansas. Convenience sampling was used to explore technology acceptance by these military learners during training at the C-130 Aircrew Training System (ATS). Permission to interview military learners was granted by the DOD and C-130 ATS site managers prior to selection of participants. Only volunteers participated in the study and this participation had no bearing on their training status. Interviews concluded after 18 were conducted because the gathered information became repetitive and no new themes emerged.

\section{Ethical Assurance}

This researcher followed the insitutional IRB approval procedures before recruiting participants. University IRB categories included: protecting student data, preventing coercion, providing clear language, and allowing for an easy method to opt out of the study (Bowen, Chingos, Lack, \& Nygren, 2012). During this study, each participant was briefed on their volunteer status and were provided an Informed Consent Form to remind them that they were free to decline participation in the study without negative repercussions and that their participation would remain anonymous (AFIRB, 2011; Schram, 2006).

In this case, confidentiality of the participants was protected by the researcher and participants were only identified by coded identifiers. Every effort was made to maintain anonymity however, signing a consent form presented a minor risk. All copies of the interviews were locked in a secure desk cabinet at the researcher's home for seven years as approved by the university (Cozby, 2009). After seven years, hard copies will be shredded or burned by the researcher. Audio copies will also be retained in the primary researcher's locked cabinet. These copies will also be destroyed at the seven year destruction time. The participants were not compensated for participation. 


\section{Materials/Instruments}

The materials included in this case study were interview protocol questions which were developed to explore each of the four constructs of the technology acceptance model (see Appendix). The interview questions were designed to reveal the perceptions that military learners have for the 360-degree lessons that include the new technology. The questions were designed around definitions of each TAM construct and they were field tested at the beginning of the study. To field test the interview questions, a separate group of aircrew members reviewed the proposed interview questions to ensure that the text was clearly understood by the participants. All the interview questions were rated acceptable for during field test which informed the interviewer that the questions should be understood. See the Appendix for the actual survey questions.

\section{Results}

The purpose of this qualitative embedded single-case study was to explore the acceptance of new technology designed and mandated for use in training. The findings are based on an analysis of 18 interviews of military learners who attended training and have completed courses using the new 360-degree technology. Descriptive demographic data were collected and semi-structured questions were used in the interviews.

A total of 27 questions were asked of 18 participants in this study. The first 20 questions were from the TAM3 model constructs and the remaining seven questions were opinion questions about the training. These questions were asked to determine the level of acceptance that these military learners had for the new training technology. Each of the three research questions were explored using a series of these questions. The participant's responses are shown in Table 1.

\section{Research question 1}

What reasons did military aircrews give for accepting new training technologies? Interview questions 1, 2, and 21 covered this question. Question 1 asked the military learners to describe their attitude toward using the 360-degree lessons. Of those responses, $83 \%$ were positive, $11 \%$ were neutral, and $6 \%$ were negative. In Question 2 the participants were asked to describe how likely they were to use the lessons in the future. A total of $67 \%$ responded positively, $11 \%$ were neutral, and $22 \%$ were negative. 
Table 1

Summary of Participants' Responses

\begin{tabular}{|c|c|c|c|c|}
\hline Question & Construct & Negative & Neutral & Positive \\
\hline 1 & Attitude & $6 \%$ & $11 \%$ & $83 \%$ \\
\hline 2 & Behavioral Intention & $22 \%$ & $11 \%$ & $67 \%$ \\
\hline 3 & Computer Anxiety & $0 \%$ & $11 \%$ & $89 \%$ \\
\hline 4 & Computer Playfulness & $22 \%$ & $0 \%$ & $78 \%$ \\
\hline 5 & Computer Self-Efficacy & $0 \%$ & $0 \%$ & $100 \%$ \\
\hline 6 & Effort Expectancy & $0 \%$ & $6 \%$ & $94 \%$ \\
\hline 7 & Facility Conditions & $11 \%$ & $17 \%$ & $72 \%$ \\
\hline 8 & Image & $39 \%$ & $6 \%$ & $56 \%$ \\
\hline 9 & Job Relevance & $0 \%$ & $0 \%$ & $100 \%$ \\
\hline 10 & Objective Usability & $0 \%$ & $6 \%$ & $94 \%$ \\
\hline 11 & Output Quality & $6 \%$ & $11 \%$ & $83 \%$ \\
\hline 12 & Perform Expectancy & $11 \%$ & $6 \%$ & $83 \%$ \\
\hline 13 & Perceived Ease of Use & $0 \%$ & $6 \%$ & $94 \%$ \\
\hline 14 & Perceived Enjoyment & $0 \%$ & $44 \%$ & $56 \%$ \\
\hline 15 & Perceived Usefulness & $17 \%$ & $0 \%$ & $83 \%$ \\
\hline 16 & Perception of External Control & $28 \%$ & $11 \%$ & $61 \%$ \\
\hline 17 & Results Demonstrability & $17 \%$ & $6 \%$ & $78 \%$ \\
\hline 18 & Social Influence & $33 \%$ & $6 \%$ & $61 \%$ \\
\hline 19 & Subjective Norm & $11 \%$ & $17 \%$ & $72 \%$ \\
\hline 20 & Voluntariness & $28 \%$ & $0 \%$ & $72 \%$ \\
\hline 21 & Describe Degree of Acceptance & $0 \%$ & $6 \%$ & $94 \%$ \\
\hline 22 & Describe Why Acceptance is Important & $0 \%$ & $0 \%$ & $100 \%$ \\
\hline 23 & What Effect on Learning & $17 \%$ & $11 \%$ & $72 \%$ \\
\hline 24 & How Helped with Checklist skills & $39 \%$ & $0 \%$ & $61 \%$ \\
\hline 25 & How Helped with Simulator or Flying & $22 \%$ & $6 \%$ & $72 \%$ \\
\hline 26 & What would Improve 360-Degree Lessons & $0 \%$ & $0 \%$ & $100 \%$ \\
\hline 27 & Is there anything more to add & $0 \%$ & $0 \%$ & $100 \%$ \\
\hline
\end{tabular}


Question 21 asked learners to describe their experience and what degree of acceptance they had for the 360-degree technology. Learners gave a $94 \%$ positive and $6 \%$ neutral acceptance rating toward the new technology. Specific themes were also noted.

Themes. When asked about their attitude toward using the new lessons, four themes that evolved (Table 2). The first theme was about the instructor's ability to use the technology themselves. The second theme was about the logistics involved with using this technology versus actually going out to the aircraft. The third theme was about the quality of the visual presentation of material. And, the final theme was in relation to the different types of learners that use the training technology.

Table 2

How Do Military Learners Accept New Technology - Attitude

\begin{tabular}{|lc|}
\hline Attitude - Toward using 360 lessons & N\% responses from the sample \\
\hline Instructor ability to use equipment & $11 \%$ \\
Logistics of training & $22 \%$ \\
Presentation style & $17 \%$ \\
Types of learner & $39 \%$ \\
\hline
\end{tabular}

When asked about a behavioral intent to use the new lessons in the future, two themes evolved (Table 3). The first theme was about who would use the training technology and the second one was why the training technology was being used.

Table 3

How Do military Learners Accept New Technology - Behavioral Intention

\begin{tabular}{|lc|}
\hline Behavioral Intention - Future use & N\% responses from the sample \\
\hline $\begin{array}{l}\text { Who would use this technology } \\
\text { Why one uses this training } \\
\text { technology }\end{array}$ & $22 \%$ \\
\hline
\end{tabular}

Four themes evolved (Table 4) when military learners were asked to describe their experience while participating in the 360-degree lessons training and what degree of acceptance they had for the 360-degree technology. Those theme 
clusters involved: use of the programs, the future, improved understanding, and the ease of using the 360 lessons. Some students used the program individually while others had an instructor demonstrate use. In the second theme, the instructors' inability to access or use the program caused some students problems. The third theme was about improved understanding for new learners. And, the fourth theme was about the ease of use.

Table 4

How Do military Learners Accept New Technology-Degree of Acceptance

\begin{tabular}{|c|c|c|}
\hline & Describe - degree of acceptance & N\% responses from the sample \\
\hline \multirow{4}{*}{ guys } & Use of the programs & $6 \%$ \\
\hline & The future & $28 \%$ \\
\hline & Improved understanding for new & $28 \%$ \\
\hline & Ease of use & $39 \%$ \\
\hline
\end{tabular}

\section{Research question 2}

Why did military learners accept the new technology provided in the training program? Every learner $(100 \%)$ provided a positive reason for accepting new technology in their training. The participants responded with a series reasons to explain their acceptance. The researcher asked the military learners to describe why their acceptance of the training was important to the completion of military job training. There were three themes that emerged from this discussion question (Table 5). The first theme was about completing the training, second was about the faith in the instructors, and third was about being user friendly.

Table 5

Why do Military Learners Accept New Technology

\begin{tabular}{|lc|}
\hline Describe why acceptance is important & N\% responses from the sample \\
\hline Training completion to know the job & $50 \%$ \\
Faith in instructors & $28 \%$ \\
User friendly & $17 \%$ \\
\hline
\end{tabular}




\section{Research question 3}

How did military learners perceive the value of the training in relation to the TAM3 factors? This research question was covered by asking a series of interview questions that specifically explored the PEOU construct and focused on the Anchor and Adjustment aspects.

Anchor construct. Interview questions 5, 16, 3, \& 4 covered the Anchor constructs of the TAM3 model (Computer Self-Efficacy, Perception of External Control, Computer Anxiety, \& Computer Playfulness, \&). The researcher asked, in Question 5, for the learners to describe how well they believed that they were able to use the 360-degree lessons. Learners responded with a $100 \%$ positive computer self-efficacy. In Question 16, learners were asked to describe how they believe that the organizational and technical infrastructure supports to use of the 360-degree lessons. Learners replied with a $61 \%$ response for positive external control, $11 \%$ neutral, and $28 \%$ negative toward the perception of external control while using the lessons and technology. Then in Question 3 the military learner was asked to describe how anxious they were when using computers. Of those responses, $89 \%$ were positive (which meant non-anxious), $11 \%$ were neutral, and $0 \%$ were negative for computer anxiety. Next in Question 4 the learners were asked to describe how natural computer use came to them. For those responses, $78 \%$ were positive, $0 \%$ was neutral, and $22 \%$ were negative for computer playfulness.

Anchor themes. One theme emerged from asking Question 5, "How well you believe you are able to use the 360-degree lessons?" (Table 6). That theme was summed up by one participant, "It's pretty straight forward."

Table 6

Perceived Value of Training - Computer Self-Efficacy

\begin{tabular}{|lc|}
\hline Computer self-efficacy & N\% responses from the sample \\
\hline Straight Forward & $100 \%$ \\
\hline
\end{tabular}

Three themes emerged from the question, asking learners to describe how they believe that the organizational and technical infrastructure supports use of the 360-degree lessons (Table 7). Themes ranged from not well supported, to supported well, and the need to improve instructor efficiency as a part of the program. 
Table 7

Perceived Value of Training - Perception of External Control

\begin{tabular}{|lc|}
\hline Perception of External Control & N\% responses from the sample \\
\hline Not well supported & $20 \%$ \\
Instruction for instructors & $39 \%$ \\
Support is good & $61 \%$ \\
\hline
\end{tabular}

While most learners had no computer anxiety, there were several warnings identified in the comments. Three themes emerged from the question, asking learners how anxious they were about computer use (Table 8). The first theme to be identified was about computer hardware and software, the next was about the logic of the course, and third was about the quality of the computer system.

Table 8

Perceived Value of Training - Computer Anxiety

\begin{tabular}{|lc|}
\hline Computer anxiety & N\% responses from the sample \\
\hline Hardware and Software frustrations & $6 \%$ \\
Course Logic & $6 \%$ \\
Quality of computer systems & $6 \%$ \\
\hline
\end{tabular}

Two themes emerged as military learners responded to the question about natural computer use (Table 9). While most of the participants acknowledged a high comfort in using computers, $20 \%$ of the users identified a medium to low comfort level when using computers.

Table 9

Perceived Value of Training - Computer Playfulness

\begin{tabular}{|l|c|}
\hline Computer Playfulness & $\begin{array}{l}\text { N\% responses from the } \\
\text { sample }\end{array}$ \\
\hline Un-Natural users & $22 \%$ \\
Natural users & $78 \%$ \\
\hline
\end{tabular}


Adjustment construct. Interview questions 14, 10, and 13 were designed to cover the Adjustment aspects of the TAM3 model (Perceived Enjoyment, Objective Usability and Perceived Ease of Use). The learners were asked in Question 14, to describe how enjoyable the 360-degree lessons were to use. Learners responded with a $56 \%$ positive (enjoyment) and $44 \%$ neutral toward the enjoyment of using the lessons and technology. In Question 10, the military learner was asked to compare using the 360-degree lessons to their perception of the effort required to use the 360-degree lessons. Of those responses, $94 \%$ were positive (little effort required) and 6\% were neutral toward the perceived effort for using the new technology. Finally, in Question 13 the learners were asked to describe how easy it was to use the 360-degree lessons. For those responses, $94 \%$ were positive and $6 \%$ were neutral for how easy it was to use the lessons.

Adjustment Themes. Three themes emerged from the question, asking learners to describe how enjoyable the 360-degree lessons are to use (Table 10). The participants enjoyed aspects of the lessons: the lessons took the right amount of time, they were not distasteful, and some learners actually enjoyed the technology.

Table 10

Perceived Value of Training - Perceived Enjoyment

\begin{tabular}{|lc|}
\hline Perceived Enjoyment & N\% responses from the sample \\
\hline Timing & $16 \%$ \\
Neutral & $44 \%$ \\
Enjoyable & $56 \%$ \\
\hline
\end{tabular}

One theme emerged from question number 10 ask learners to compare using the 360-degree lessons to their perception of the effort required to use the 360degree lessons (Table 11). Universally, the participants commented that the lessons were as easy to use as they were perceived to be easy to use.

Table 11

Perceived Value of Training - Objective Usability

\begin{tabular}{|lc|}
\hline Objective Usability & N\% responses from the sample \\
\hline Easy or easier than perceived & $100 \%$ \\
\hline
\end{tabular}


One theme surfaced from the question: describe how easy it is to use the 360-degree lessons (Table 12). The theme was that it was relatively easy to use.

Table 12

Perceived Value of Training - Perceived Ease of Use

\begin{tabular}{|lc|}
\hline Perceived Ease of Use & N\% responses from the sample \\
\hline Easy to use & $100 \%$ \\
\hline
\end{tabular}

The Voluntary construct was also explored during this mandatory use of technology situation. Military learners were also asked to describe their perception that using the 360-degree lessons was non-mandatory (Table 13). The course syllabus called for learners to use the 360-degree technology to meet leaning objectives. However, instructors were authorized to complete the learning objectives by other means if necessary. The lessons were designed to be instructor led, student led, or a blend of both methods. If the system was unresponsive, the instructor was incompetent, or the students were past the level of training encompassed in the objective (at a higher skill level because of previous experience) use of the technology could be introduced but not used. However, all participants in this study were exposed to and used the new training technology. Three themes were identified for the Voluntariness construct: a useful tool, difficulty during instruction, and highly experienced military learners.

Table 13

Perceived Value of Training - Voluntariness

\begin{tabular}{|l|l|}
\hline Voluntariness & $\begin{array}{l}\text { N\% responses from the } \\
\text { sample }\end{array}$ \\
\hline Useful tool & $6 \%$ \\
Difficulty during instruction & $12 \%$ \\
Highly experienced & $6 \%$ \\
\hline
\end{tabular}

\section{Evaluation of Findings}

This research purpose was to study military learners' acceptance of new technology designed and mandated for use in training. In this case study new information was added to the body of knowledge about technology acceptance in mandatory situations. Specifically, military learners were required to use the 360degree lessons to meet training objectives. During previous research, it was shown 
that "acceptance" had been confused with "use" when learners were directed to use the given technology. In this case study, military learners used a new technology that was applied in three ways. The methods were instructor led; individual led, and blended styles. The instructor led method is self explanatory, the second method was instructor introduced and individual led, and the third was a blended style of instruction where the student explored and the instructor guided as instruction was needed.

\section{Research question 1}

The first question was what reasons did military aircrews give for accepting new training technologies? The participants in the study relayed that their acceptance was contingent upon four factors: the instructors' ability, the training location, the method used to present the material, and the type of learner being taught. The learners also revealed that their intention was to accept the technology if the subject matter was "appropriate" to their level of training. In other words, the experience level of the learner influenced the learners' acceptance of the new technology. As far as who should use the technology in this training scenario, participants agreed that initial learners would be the best target audience for the current lessons using the technology. The technology was perceived as easy to use; a reason given to accept the new technology in this mandatory learning scenario. The literature revealed that the perceived ease of use of a technology in mandatory situations increased the perception of usability (Daniel, 2011; Venkatesh \& Bala, 2008).

A review of the technology acceptance model showed that behavior intention is linked to the attitude of the learner (Show-Hui \& Hsu, 2013). In this research the learners mentioned that their attitude was influenced by the instructors' ability to use equipment and the logistics of getting to a training location. Researchers have shown that the attitude and behavior intention of learners to accept new technology was largely dependent upon the instructions which were given to explain how to operate new equipment (Nistor, Baltes, \& Schustek, 2012). Overall the participants' attitudes were $83 \%$ positive toward using this technology, $11 \%$, were neutral and $6 \%$ were negative. This research also found that $70 \%$ of the participants identified that the presentation style was important and 39\% of the participants referred to their individual learning style as a factor in how they accept technology.

Behavior intention toward using this technology in the future was $67 \%$ positive, $11 \%$ neutral, and $22 \%$ negative. Several participants stated that their future use would depend upon the target audience for new course material. This behavior 
intention seems to follow the research literature (Ohtake, Lazarus, Schillo, \& Rosen, 2013; Cronan \& Douglas, 2012; Osman \& Bakar, 2012). The more experienced participants in the group found the material too basic to review again with the new technology. However they did reveal that if more advanced lessons would be developed in the future, they would be willing to use the new technology.

This research seems to support previous efforts that illustrate a need for instructor guidance with new technology training despite the perceived ease-of-use because sometimes written instructions are unclear. Learners will "shut down" when instructions are too complex, said Participant 16. Adeptness at manipulating advanced technology tools depends upon the educator and three important factors: texts, tools, and talk (Philip \& Garcia, 2013). Researchers have noted that with the increased presence of technology in classrooms, teachers actually become more indispensable to explain the possibilities of new technologies (Philip \& Garcia, 2013). In this case study, the instructors' perceived ability to use the new technology has contributed to the participants' acceptance level for the technology; which seems to be congruent with previous research.

\section{Research question 2}

The second research question asked why military learners accept the new technology provided in the training program. The TAM literature showed that participants used new technology for two reasons; perceived usefulness or perceived ease-of-use. In this case, participants noted that completion of the training program was a major reason for acceptance of the technology. Participants explained that they chose to accept the technology to enhance their job knowledge, to make the job easier, and to stay ahead in the Air Force. Each of these explanations points toward the perceived usefulness of the training. Perceived usefulness has been explained by learners in the literature as the pain one has to endure to achieve something; or what cognitive effort is necessary to achieve a learning goal. In this case, $83 \%$ of the learners felt that the technology was useful while $17 \%$ did not see the usefulness.

These participants also identified faith in their instructor as a reason to accept the new technology. Some learners approached training with an open mind and accepted the technology because the ATS instructors and managers felt that the technology was useful. Other learners accepted the training technology because their instructors were perceived to be smarter; they accept because instructors have the experience that young learners were trying to achieve. Learners did not accept the technology when the instructors and infrastructure were not supportive. Participants were turned off by technology when it was not user-friendly. User- 
friendliness was important but also, instructors need to be able to demonstrate the equipment and the infrastructure needs to be in place to support the computer programs.

These findings are consistent with the literature review. When a training program is unfamiliar to a student it is considered to be new technology. In some cases when new technologies are developed they are more powerful and complex which may cause learners to devote more energy toward learning that new technology (Show-Hui \& Hsu, 2013). In the TAM's Perceived Usefulness construct, researchers have shown that learners accept new technology if they trust the technology to provide a positive transfer of knowledge (Aghdaie, Piraman, \& Fathi, 2011). Trust is a predictor of user behavior intention; this research found that trust in the instructors was identified as a major factor for learners' acceptance of technology. The Perceived Ease-Of-Use factor also contributed to why learners accept new technology. The literature showed that the ease of use factor and information quality assurance were main predictors of the trust attitude (Aghdaie et al., 2011).

With the increased presence of technology in classrooms, teachers have actually become more indispensable to explain the new technologies and this literacy has been identified as a key to future technology jobs (Philip \& Garcia, 2013). During this case study $83 \%$ of the participants identified that perceived usefulness was key for acceptance and $94 \%$ identified perceived ease-of-use as a determinant for technology acceptance. This information was consistent with the literature and was expected. However, this research found that the level of trust in the instructors' input about the technology was important.

\section{Research question 3}

Question three was how do military learners perceive the value of the training in relationship to the TAM3 factors. In the TAM3, the focus of interest was on the perceived ease-of-use construct (PEOU) and 94\% of the participants perceived this technology as easy to use. The PEOU construct has six subconstructs that are measures for acceptance. Those six sub-constructs are divided into two areas defined as Anchors and Adjustments. The anchor sub-constructs deal with an individual's internal feelings of: anxiety, playfulness, self-efficacy, and perceived control. These constructs come from an internal source in the participant. The adjustment constructs are terms used to describe perceived enjoyment and objective usability.

In this case study, participants explained that common sources of frustration contributing to computer anxiety were hardware problems, delays with software 
applications, and computer logic. However, $89 \%$ of the participants found that with this technology they had no computer anxiety and the other $11 \%$ of the participants were neutral. The computer playfulness construct was mixed among the participants, $80 \%$ self identified as natural users and $20 \%$ as unnatural users. Despite this mixed computer comfort level among participants, $100 \%$ of the participants stated that they were confident in their ability to use the technology. This $100 \%$ computer self-efficacy showed that the new technology was easy to use. The 4th Anchor construct, perceptions of external control, posited reasons why participants would not accept new technology training. In this case, the perceived barriers to ease-of-use included instances when technology was not supported by the instructors and not supported by the infrastructure (Al-Dosari, 2011 \& Teklu, 2010). Instances when instructors did not support the training included the instructors' inability to navigate through the programs while instructing or their inability to open a program because of hardware and software problems. Conversely, when instructors were skilled at using the technology and the hardware and software were in place, the participants enjoyed the training. In this research the perception of external control was rated $61 \%$ positive, $11 \%$ neutral, and $28 \%$ negative.

To summarize the Anchor constructs of Computer Anxiety, Playfulness, Self-Efficacy, and Perceived External Control, 100\% of the participants stated they had no computer anxiety, $78 \%$ were natural computer users, $100 \%$ had the selfefficacy to operate the system confidently, and $61 \%$ felt positive toward the perceived external control. As for the Adjustment constructs of Perceived Enjoyment and Objective Usability, 56\% of the participants' perceived enjoyment from the new technology and $94 \%$ saw the technology as objectively usable.

Overall, $94 \%$ of the participants rated the Perceived Ease of Use of this new technology as positive. The PEOU construct measured a perceived level of effort that participants have for using the technology to complete the training.

The Voluntary construct was also explored during this mandatory use of technology situation. Several of the learners felt that the new technology was acceptable enough that they would volunteer to use the technology on their own for future study. Learners explained that sometimes the equipment did not work and sometimes the instructor had difficulty operating the equipment. This caused a delay in the training which affected the student's perception of the new technology as useful or easy to use. Past researchers have explained that the acceptance of new technology is dependent upon the instructors' ability to demonstrate that technology. In mandatory use situations perceived ease of use enhances a users' 
willingness to accept that technology. This finding with military learners in mandatory use situations was consistent with the literature.

\section{Implications and Conclusions}

The problem addressed in this study was that in the midst of shrinking budgets, industry and Department of Defense leaders were charged with completing critical training (Dunlap, 2011; Gates, 2010; Hofheimer, 2010). To remain within reduced budgets, leaders in the USAF have endorsed technology as an adjunct to traditional training methods (Steenberge \& Weigand, 2011; USAF, 2012). One requirement set by USAF trainers for new training technology, was that it must be accepted by learners (USAF, 2012). The purpose of this qualitative embedded single-case study was to explore the process of how and why military learners accept new technology that was designed for their training.

\section{Implications}

The authors of this study explored the understanding of how military learners accept new technology, why they accept it, and the value they put on their training. Upon completion of military training, learners are potentially thrust into national defense conflicts so the training must be well designed and thorough.

Research question 1. During the analysis, it was noted that the presentation style of material and that an individual's learning style were linked to how participants accept new technology. These findings need to be considered when developing new technology so that tools are available when the learners need them, to optimize training. If not, learners at this location and those in other industries may not achieve the desired learning objectives.

Research question 2. This case found that the level of trust in the instructors' input about the technology was important to learners. The instructors must understand that that the communication about the material, equipment, and technology sends a message to the students about the importance of the training. Course developers and managers must provide the best support available to allow the instructors to succeed and train the students. Barring this, learners in new training situations will avoid the new technology and possibly fail in training.

Research question 3. This researcher found that in mandatory use situations such as this military training, the perceived ease of use of the technology enhances a users' willingness to accept that technology. Instructors and technology

developers must work together to produce technology that is easy to use with the 
goal of creating the best learning experience for the students. A better way of training these military learners may be missed if instructors and developers do not work together. Also, in similarly developed industry training where acceptance is "mandatory," the tools that are developed must be appropriate for the learners.

\section{Recommendations}

Findings from this study may be used by the USAF, the ATS, and other trainers to improve technology in training programs. Business and industry leaders may adopt these recommendations and adapt their training courses. Recommendations for improvement include actions for instructors, learners, and the organization.

\section{Recommendations in practice}

Managers should ensure that instructors have the best opportunity to learn the new technology before they train students (Rhode, 2014; Vogel-Walcutt, Del Guidice, Fiorella, \& Nicholson, 2013). Findings from this study show that the learners accept the training technology because they trust their instructors who have a depth of experience. The second finding was that, learners have different background experience levels and learning styles; so learners should be provided the opportunity to study with the new technology on their own schedule (Read, Robertson, \&McQuilken, 2011). Access of material is important during nonbusiness hours because the military learner studies around the clock (Gafni et al., 2011; Osman \& Bakar, 2012). Therefore it is important to provide opportunities for learners to use the programs on personal computers at a convenient time. Finally, this case study found that because participants have different learning styles, training managers should produce more lessons using this technology to improve the course opportunities and increase flexibility (Daniel, 2011; Fletcher, 2009). It was noted that that the sky is the limit for this technology, a "sequel" or more systems should be developed with the new technology.

\section{Recommendations for future research}

Develop a quantitative study to determine how much the TAM3 impacts student abilities to accept training in mandatory situations. Conduct a qualitative study using the more advanced TAM methods to learn more about how to advance training methods for learners. Develop new methods to apply the TAM models for technology acceptance for business and industry in mandatory situations. 


\section{Conclusions}

The specific problem explored in this study was how and why military learners accepted new technology that was designed and mandated for use in their training (Cane et al., 2010). It was unclear exactly how the TAM could be used to explain technology acceptance while training military learners (Alias, 2012; Gafni et al., 2011). In this case study, the TAM3 was applied to this mandatory learning situation in a military context. This knowledge may be communicated to industry and military training managers. With reduced budgets, leaders in the USAF have endorsed technology as an adjunct to traditional training methods (Steenberge \& Weigand, 2011; USAF, 2012). A requirement set by USAF trainers is that new training technology must be accepted by learners (USAF, 2012).

The purpose of this qualitative embedded single-case study was to explore the process of how and why military learners accepted new technology that was designed for training. This case study provided themes that emerged from 27 questions developed from the TAM3 research guide (Venkatesh \& Bala, 2008). The results gathered and compiled described how learners use technology, why learners use technology, and how they perceive the value of their training.

Managers should use the current technology to include other topics for study. Instructors should remember that they are a large part in why military learners accept technology and they must remain current with current technology. Finally, training developers may adapt this technology for programs in their industries. Future research should study quantitative and qualitative methods for technology acceptance in other business training arenas. 


\section{References}

Aghdaie, S.F.A, Piraman, A., \& Fathi, S. (2011). An analysis of factors affecting the consumer's attitude of trust and their impact on internet purchasing behavior. International Journal of Business and Social Science, 2(23), 147-158. Retrieved from

http://www.ijbssnet.com/journals/Vol_2_No_23_Special_Issue_December _2011/16.pdf

Ajzen, I. (1991). The theory of planned behavior. Organizational Behavior and Human Decision Processes, 50(2), 179-211.

Alias, N. A. (2012). Design of a motivational scaffold for the Malaysian elearning environment. Journal of Educational Technology \& Society, 15(1), 137. Retrieved from http://www.ifets.info/journals/15_1/13.pdf

Cane, S., McCarthy, R., \& Halawi, L. (2010). Ready for battle? A phenomenological study of military simulation systems. The Journal of Computer Information Systems, 50(3), 33-40. Retrieved from http://www.iacis.org/jcis/jcis_toc.php?volume $=50 \&$ issue $=3$

Chuttur, M.Y. (2009). Overview of the technology acceptance model: Origins, developments and future directions. Indiana University, Sprouts: Working Papers on Information Systems. Retrieved from http://sprouts.aisnet.org/785/1/TAMReview.pdf

Daniel, F. (2011). Diversity as technology: A new perspective. Journal of Diversity Management, 6(2), 31. Retrieved from http://journals.cluteonline.com/index.php/JDM/article/view/5483/5568

Dass, S., Dabbagh, N., \& Clark, K. (2011).Using virtual worlds: What the research says. Quarterly Review of Distance Education, 12(2), 95-111, 149.

Davis, F. D. (1989). Perceived usefulness, perceived ease of use, and user acceptance of information technology. MIS Quarterly, 23(2), 145-158. Retrieved from http://misq.org/perceived-usefulness-perceived-ease-ofuse-and-user-acceptance-of-information-technology.html 
Dunlap, C. J. Jr. (2011). The military-industrial complex. Daedalus, 140(3), 135147. Retrieved from http://www.deepdyve.com/lp/mit-press/the-militaryindustrial-complex-AgrIqNo0mt

Farrell, L. P. Jr., (2014). Defense strategy in a square corner. National Defense Magazine, 99(9), 6.

http://www.nationaldefensemagazine.org/archive/2014/September/Pages/ DefenseStrategyinaSquareCorner.aspx

Fishbein, M., \&Ajzen, I. (1975). Belief, attitude, intention and behavior: An introduction to theory and research: Reading. MA: Addison-Wesley.

Fletcher, J. D. (2009). Education and training technology in the military. Science, 323.DOI:10.1126/science.1167778.

Gafni, R., Shaul, L., \& Tauber, D. (2011). E-Learning diurnal time patterns in the Navy. Issues in Informing Science and Information Technology, 8(1). Retrieved from http://iisit.org/Vol8/IISITv8p377-393Gafni267.pdf

Gates, R. M. (2010). DOD news briefing with secretary gates from the pentagon," news transcript, U.S. Department of Defense, August 9, 2010. http://www.defense.gov/Transcripts/ Transcript.aspx?TranscriptID=4669.

Ghazizadeh, M., Lee, J. D., \& Boyle, L. N. (2012). Extending the technology acceptance model to assess automation. Cognition, Technology \& Work, 14(1), 39-49. doi: http://dx.doi.org/10.1007/s10111-011-0194-3

Gibbons, A. S. \& Fairweather, P. G. (2000). Training and Retraining: A Handbookfor Business, Industry, Government, and the Military (Tobias \& Fletcher eds.). New York, NY: Macmillan Gale Group

Hedman, J., \&Gimpel, G. (2010). The adoption of hyped technologies a qualitative study. Information Technology Management, 11:161-175. doi: 10.1007/s10799-010-0075-0

Hofheimer, J. (2010, December 30). Trainers laid off at air base. The Arkansas Leader. Retrieved January 28, 2011 from http://arkansasleader.blogspot.com/2010/12/top-story-trainers-laid-off-atair-base.html 
Holden, R. J., \& Karsh, B. T. (2010). The technology acceptance model: Its past and its future in health care. Journal of Biomedical Informatics, 43(1), 159-172. http://dx.doi.org/10.1016/j.jbi.2009.07.002

Hu, A. W., \& Tsai, W. M. (2009). An empirical study of an enjoyment-based response hierarchy model of watching MDTV on the move. Journal of Consumer Marketing, 26(2), 66-77. doi: 10.1108/07363760910940438

Jennings, J. (2010). Humvee rollover trainer. Professional Safety, 55(7), 24-30. Retrieved from http://www.asse.org/education/seminarfest13/docs/PSJ\%20Articles/Sem\% 2029/Human\%20factors\%20analysis\%20and\%20classification\%20dept\% 20of\%20defense_Jennings_0608.pdf

Koblen, I., \&Kovacova, J. (2012). Selected information on flight simulators-main requirements, categories and their development, production and using for flight crew training in the both Slovak Republic and Czech Republic conditions. INCAS Bulletin, 4. Retrieved from http://bulletin.incas.ro/files/koblen_kovacova_v4_iss_3_full.pdf

Lee, H.-H., \& Chang, E. (2011). Consumer attitudes toward online mass customization: An application of extended technology acceptance model. Journal of Computer-Mediated Communication, 16(2), 171-200. Retrieved from doi: 10.1111/j.1083-6101.2010.01530.x

Mangin, J. L., Bourgault, N., León, J. A. M., \& Guerrero, M. M. (2012). Testing control, innovation and enjoy as external variables to the technology acceptance model in a north american french banking environment. International Business Research, 5(2), 13-26. doi: 10.5539/ibr.v5n2p13

Mardis, M. A., Hoffman, E. S., \& Marshall, T. E. (2008). A new framework for understanding educational digital library use: re-examining digital divides in U.S. schools. Int J Digit Libr, 9, 19-27. doi: 10.1007/s00799-008-0035$\mathrm{Z}$

Osman, K., \& Bakar, N. A. (2012). Educational computer games for malaysian classrooms: Issues and challenges. Asian Social Science, 8(11), 75-84. doi: 10.5539/ass.v8n11p75 
Palomäki, E., Stigzelius, E., \&Vartiainen, M. (2010). State of the art-Overview of new applications, practices and concepts in utilizing technology in education, their use in work contexts, global/local aspects for multichannel online services. Retrieved from http://scholar.google.com/scholar?q=Palom\%C3\%A4ki\%2C+E.\%2C+Stig zelius $\% 2 \mathrm{C}+\mathrm{E} . \% 2 \mathrm{C}+\% 26+\mathrm{Vartiainen} \% 2 \mathrm{C}+\mathrm{M} .+\% 282010 \% 29 \& \mathrm{btnG}=\& \mathrm{hl}$ $=$ en\&as_sdt $=0 \% 2 \mathrm{C} 4$

Piraman, A. (2011). An analysis of factors affecting the consumer's attitude of trust and their impact on internet purchasing behavior. International Journal of Business and Social Science, 2(23), n/a. Retrieved from http://www.ijbssnet.com/journals/Vol_2_No_23_Special_Issue_December _2011/16.pdf.

Philip, T. M., \& Garcia, A. (2015). Schooling mobile phones: Assumptions about proximal benefits, the challenges of shifting meanings, and the politics of teaching. Sage Journals, 29(4) 676-707. doi: 10.1177/0895904813518105

Quazi, A., \&Talukder, M. (2011). Demographic determinants of adoption of technological innovation. The Journal of Computer Information Systems, 52(1), 34-42. Retrieved from http://www.iacis.org/jcis/jcis_toc.php?volume=52\&issue $=1$

Read, W., Robertson, N., \&McQuilken, L. (2011). A novel romance: The technology acceptance model with emotional attachment. Australasian Marketing Journal, 19(4), 223-229. doi: http://dx.doi.org/10.1016/j.ausmj.2011.07.004

Rhode, J. (2014). Hierarchy of instructional design. Retrieved from: http://www.jasonrhode.com/hierarchy-of-instructional-design

Schofield, D. (2012). Mass effect: A chemical engineering application of virtual reality simulator technology. Merlot Journal of Online Learning and Teaching. Retrieved from: http://jolt.merlot.org/vol8no1/schofield_0312.pdf

Steenberge, K., \&Wiegand, L. (2011).C-130 360-degree virtual tour program. 2011 AETC Symposium. San Antonio, TX.

Talukder, M. (2012). Factors affecting the adoption of technological innovation by individual employees: An Australian study. Procedia-Social and Behavioral Sciences, 40, 52-57. 
United States Air Force. (2012). Flying operations aircrew training, Air Force Instruction, 11-202, Volume 1. Washington, DC: U.S. Government Printing Office.

Venkatesh, V. (1999). Creation of favorable user perceptions: Exploring the role of intrinsic motivation. MIS Quarterly, 23(2), 239-260. Retrieved from http://misq.org/creation-of-favorable-user-perceptions-exploring-the-roleof-intrinsic-motivation.html

Venkatesh, V. (2010). Technology acceptance, summary of technology acceptance models, Personal Website. Retrieved from http://www.vvenkatesh.com/IT/organizations/Theoretical_Models.asp.

Venkatesh, V. \&Bala, H. (2008). Technology acceptance model 3 and a research agenda on interventions. Decision Sciences, 39(2), 272-315. doi: 10.1111/j.1540-5915.2008.00192.x

Venkatesh, V. \& Davis, F.D. (2000). A theoretical extension of the technology acceptance model: four longitudinal field studies. Management Science, 46(2), 186-204. doi: 10.1287/mnsc.46.2.186.11926

Vogel-Walcutt, J. J., Del Guidice, K., Fiorella, L., \& Nicholson, D. (2013). Using a video game as an advance organizer: Effects on development of procedural and conceptual knowledge, cognitive load, and casual adoption. Journal of Online Teaching, Manuscript under review. Retrieved from http://jolt.merlot.org/vol9no3/vogel-walcutt_0913.htm

Yousafzai, S. Y., Foxall, G. R., \& Pallister, J. G. (2007). Technology acceptance: A meta-analysis of the TAM: Part 1. Journal of Modelling in Management, 2(3), 251. doi http://dx.doi.org/10.1108/17465660710834453 


\section{Appendix}

\section{Participants' Questions}

Interview questions used in this research were adapted from the TAM3 (Venkatesh \& Bala, 2008). Each question was used to probe an aspect of technology acceptance. The participants' answers provide a better understanding of how and why military learners' accept technology developed for their training. Questions follow:

1. Describe your attitude toward using the 360-degree lessons.

2. Describe how likely you are to using the 360-degree lessons in the future.

3. Describe how anxious you are when you use computers.

4. Describe how natural computer use comes to you.

5. Describe how well you believe that you are able to use the 360-degree lessons.

6. Describe how easy you believe the 360-degree lessons are to use.

7. Describe how well you believe that the organization and technical support exists to run the 360-degree lessons.

8. Describe how the use of the 360-degree lessons enhances one's status.

9. Describe how you perceive the 360-degree lessons are relevant to your job.

10. Compare using the 360-degree lessons to your perceptions of the effort required to use the 360-degree lessons.

11. Describe how you believe the 360-degree lessons help you perform your job.

12. Describe the degree to which you believe that using the 360 -degree lessons will help you in your job performance.

13. Describe how easy it is to use the 360-degree lessons.

14. Describe how enjoyable the 360-degree lessons are to use.

15. Describe how you believe that using the 360-degree lessons will help you attain gains in your job performance.

16. Describe how you believe that the organizational and technical infrastructure supports use of the 360-degree lessons.

17. Describe the results of using the 360-degree lessons.

18. Describe how you feel when important people, in your life, know that you use them.

19. Describe the perception that most people who are important to you think that you should or should not perform the 360-degree lessons.

20. Describe the extent to which you perceive that using the 360-degree lessons is non-mandatory.

21. Describe your experience while participating in 360-degree lessons training and what degree of acceptance you have for the 360-degree lessons technology?

22. Describe why your acceptance is important to the completion of military job training. 
23. What effect has the experience of using the 360-degree lessons had on your military learning experience?

24. How have the 360-degree lessons experience helped you develop checklist skills and confidence?

25. How did your experience with 360-degree lessons add or detract from your simulator or flying experience?

26. What would improve the educational technology experience, with respect to 360-degree lessons, to help you develop your systems skills and confidence in job performance?

27. Is there anything that has not been asked that would help this interviewer understand your 360-degree lessons experience? 